\title{
大阪湾で麻痺性貝毒により毒化したアカガイ,トリガイにおける 毒量抢よび毒成分の経時変化と種間の差異
}

\author{
山本圭吾, $1 *$ 及川 寛 ${ }^{2}$
}

(2017 年 1 月 18 日受付， 2017 年 3 月 11 日受理， 2017 年 5 月 19 日 J-STAGE 早期公開)

1 (地独) 大阪府立環境農林水産総合研究所水産技術センター, 2 (国研) 水産研究・教育機構中央水産研究所

Temporal changes and differences in the toxin contents and the profiles between arc shell and Japanese cockle contaminated with paralytic shellfish toxin in Osaka Bay, eastern Seto Inland Sea, Japan

\section{KEIGO YAMAMOTO ${ }^{1 *}$ AND HIROSHI OIKAWA²}

\begin{abstract}
${ }_{1}^{1}$ Marine Fisheries Research Center, Research Institute of Environment, Agriculture and Fisheries, Osaka Prefecture, Sennan, Osaka 599-0311, '2National Research Institute of Fisheries Science, Japan Fisheries Research and Education Agency, Yokohama, Kanagawa 236-8648, Japan
\end{abstract}

The causative dinoflagellate blooms of paralytic shellfish toxins (PSTs) and changes in the toxin contents and the profiles in both arc shell Scapharca broughtonii and Japanese cockle Fulvia mutica in Osaka Bay for three years from 2013 to 2015 were investigated. During the investigation, the toxic dinoflagellate Alexandrium tamarense and $A$. catenella occurred in Osaka Bay. A. tamarense was the most important causative species in contamination of bivalves with PSTs. Contamination and detoxification in arc shell with PSTs were slower than those in Japanese cockle and slight amounts of PSTs remained in the arc shell throughout the year. On the other hand, PSTs in Japanese cockle were not detected after the end of bloom of $A$. tamarense. The dominant toxins of arc shell were GTX2 and GTX3 and relative ratio of STX in the arc shell increased with decontamination of toxins. In contrast, the dominant toxins in Japanese cockle were $\mathrm{C} 1$ and $\mathrm{C} 2$. In conclusion, the rate of GTX1 and GTX4 increased during the bloom of $A$. tamarense in both species. It was suggested that toxins in Japanese cockle were rapidly excreted without any in vivo conversions of toxins from the causative dinoflagellates.

キーワード : アカガイ, 種間差, 毒成分, トリガイ, 麻痺性貝毒

麻痺性貝毒は，渦鞭毛藻の一種であるAlexandrium 属や Gymnodinium 属の有毒種が生産した麻痺性貝毒を プランクトン捕食者である二枚貝類が蓄積し, 毒化した 二枚貝をヒトが喫食することにより起こる自然毒中毒で ある。麻痺性貝毒は 1980 年代までは主に東北, 北海道 海域において, Alexandrium tamarense を原因種とする ホタテガイ Mizuhopecten yessoensis やムラサキイガイ Mytilus galloprovincialis 等の毒化に限られていたが, 1980 年代後半より, 東海地方以西の西日本でも $A$. tamarense に加えGymnodinium catenatum などによるア サリRuditapes philippinarum, ヒオウギガイChlamys nobilis, ムラサキイガイなどの毒化が発生し, 貝毒発生
海域の広域化, 毒化貝種の多様化が進んでいる。1-3)

大阪湾では 1960 年代から赤潮を対象としたプランク トンモニタリングが行われていたが，貝毒原因プランク トンである A. tamarense や同属のA. catenella などの出 現は確認されるものの, 毒化を引き起こすほどの増殖事 例はみられなかった。しかし，2002 年春季に同海域で 初となるA. tamarense による規制值 $\left(4 \mathrm{MUg}^{-1}\right)$ を超

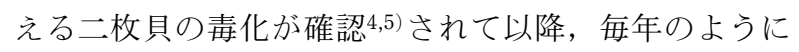
A. tamarense の増殖と二枚貝の毒化が確認されるように なった。典型的な富栄養海域とされる大阪湾では 2002 年の毒化以前はほとんど問題にされてこなかったが, 2007 年, 2011 年, 2013 年には海域での増殖に加え, 
大阪湾奥に流入する淀川の感潮域でも確認されただけで なく赤潮状態にまで増殖するなど, ${ }^{7-10)}$ 増殖の規模は拡 大傾向にある。さらに, 2005 年には A. catenella でも赤 潮が確認されたことに加え，G. catenatum，A. tamiyavanichii の出現も確認されている。大阪湾では西 日本で一般に問題となるマガキCrassostrea gigas やアサ リだけでなく，底曳き網で漁獲されるアカガイ Anadara broughtonii, トリガイ Fulvia mutica, さらに は淀川感潮域で漁獲されるヤマトシジミCorbicula japonica が麻痺性貝毒により毒化する。五) 中でもアカガ イ, トリガイは大阪湾の底曳き網漁業に抢いて重要な漁 業対象種であり, 春季には年間で最も価格が高いことも あり, 麻痺性貝毒による出荷自主規制で生じる漁業被害 は大きい。そのため, 両種に打ける麻痺性貝毒成分の蓄 積動態は生産現場に掞いて重要な情報となる。

本報では, 2013 年から 2015 年の 3 年間, 年間を通 じて麻痺性貝毒原因プランクトンを調査するとともに, 春季を中心にアカガイ, トリガイの毒力拈よび毒成分組 成の推移を調查し，原因プランクトンの増殖と毒組成の 関係, 毒量変化の両種に抢ける差異について検討した結 果を報告する。

\section{材料と方法}

麻痺性貝毒原因プランクトン調査 調查は 2013 年 1 月から 2015 年 12 月に月 2 回から 4 回の頻度で行っ た。月の上旬に Fig. 1(a) に示した大阪湾全域の 20 定点
で，それ以外の調査日は Fig. 1b に示した大阪湾東部の 14 定点ないし定点 A を除いた 13 定点に扔いて麻痺性 貝毒原因プランクトンの栄養細胞密度を調査した。調查 は大阪府立環境農林水産総合研究所調查船「打打さか (2013 年 1-2 月 : $28 \mathrm{t}, 2013$ 年 3 月以降 : $19 \mathrm{t}$ の新造 船)」により行った。各定点で表層水をバケツにより採 水し, 一部については現場で $25 \%$ グルタルアルデヒド 水溶液を最終濃度 $2.5 \%$ になるように加えて固定した。 試水は実験室に持ち帰り, 無固定の試水について生物顕 微鏡下で $1 \mathrm{~mL}$ 中の細胞数を計数した。Alexandrium 属 については固定した試水について, Calcofluor white で 染色した細胞の鎧版観察を行い, 第一頂板の腹孔の有無 により種を同定した。さらに，未固定試料の一部につい ては核酸クロマトグラフ11 により種の分子同定を行っ た。

二枚貝の試料採取と処理 アカガイ, トリガイは Fig. 1(b)に示した大阪府中部に位置する泉佐野漁港に 掞いて, 底曳き網の一種である石桁網で漁獲された漁獲 物を入手した。調查は A. tamarenseによる毒化盛期で ある 2-5 月は週 1 回, その他の月は月 1 回としたが， 毒量が規制值を上回った場合, 6 月以降についても行政 による安全宣言が出るまで毎週のサンプリングを行った。 2 月- 5 月および規制期間においては石桁網により漁業 を行っている漁業者 1 統に依頼し, 漁場の聞き取りを 行った上でサンプルを入手した。その他の時期について は市場に水揚げされた漁獲物をランダムにサンプリング

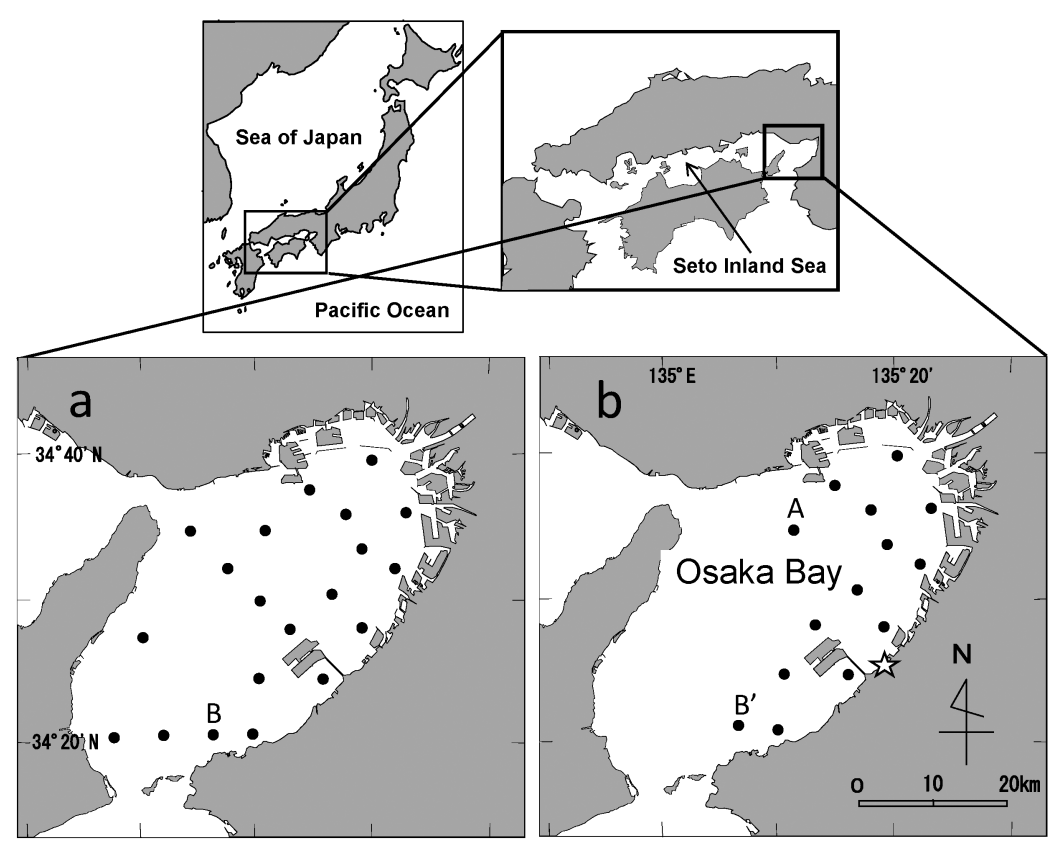

Fig. 1 Locations of the sampling stations for monitoring of causative paralytic shellfish poisoning dinoflagellate (closed circles) and a sampling port for bivalves (star) in Osaka Bay: (a) Stations for the samplings on every first Monday and Tuesday in each month, (b) stations for the samplings on other Mondays. A, Station for samplings usually on every third Monday (middle of month); B and B', nearby stations, so treated as the same station. 
した。ただし, サンプルを入手した漁業者からは可能な 限り漁場の聞き取りを行った。入手したサンプルは原則 的に軟体部重量 $100 \mathrm{~g}$ 以上になるように複数の個体を処 理したが，漁獲が著しく少なかった場合は 1 個体のみ からなる試料ないしは欠測となることもあった。マウス 試験による毒力の測定は公定法12)に従い, サンプルを ホモジナイズ後, 酸性条件で煮沸し $4^{\circ} \mathrm{C}$ で $3000 \mathrm{rpm}$, 10 min の遠心分離を行い, 上清をマウス試験用の抽出 液とした。

二枚貝の毒成分分析 アカガイ, トリガイに抢ける毒 成分の分析は Oshima ${ }^{13)}$ が報告したポストカラム蛍光化 法により行い, 分析用標準品は gonyautoxin 1 (GTX1), GTX2, GTX3, GTX4, decarbamoyl GTX2 (dcGTX2), dcGTX3, N2 1-sulfocarbamoylgonyautoxin 2 (C1), N2 1-sulfocarbamoylgonyautoxin 3 (C2), neosaxitoxin (neoSTX), decarbamoylsaxitoxin (dcSTX), GTX5, GTX6, saxitoxin（STX）の計 13 成分を用いた。HPLC 分析装 置は Hitachi 製の L-7250 オートサンプラー，L-7100 送液ポンプ, L-7300 反応槽 $\left(65^{\circ} \mathrm{C}\right), \mathrm{L}-7480$ 蛍光検出 器（励起波長 $330 \mathrm{~nm}$, 蛍光波長 $390 \mathrm{~nm}$ ) を使用し, 分析用カラムは Inertsil C8-3 (GL サイエンス, $4.6 \mathrm{~mm}$ id $\times 250 \mathrm{~mm}$ ）を用いた。な抢，HPLC 分析值から毒力 を求めたが, 毒力の算出には大島 ${ }^{13)}$ が報告した比毒性 值（以下，HPLC 毒力とする）を用いた。

\section{結果}

麻痺性貝毒原因プランクトン栄養細胞の年別出現状況 2013 年から 2015 年のプランクトン調查で確認された 麻痺性貝毒原因種は A. tamarense と A. catenellaで, こ れまで大阪湾で確認事例 (http://www.kannousuikenosaka.or.jp/suisan/gijutsu/kaidoku/mahi.html, 2016 年 12 月 8 日）のある G. catenatum, A. tamiyavanichii は本 調査期間中に確認されなかった。Fig. 2 に 2013 年から 2015 年に打ける A. tamarense 打よびA. catenellaの年 別出現状況を示した。

Alexandrium tamarense は 2013 年 2 月中旬から出現 が確認され，4 月上旬まで 10 cells $\mathrm{mL}^{-1}$ 未満で推移し たが，4月中旬にかけて急速に増殖し，4月 15 日に 714 cells $\mathrm{mL}^{-1}$ で最大となった後減少し，5 月下旬には 確認されなくなった。2014 年は 2 月上旬に確認された 後, 3 月上旬まで確認されず, その後も 3 月下旬まで低 密度であった。4 月上旬から急速に増殖し, 4 月中旬に いったん減少したが， 4 月 22 日に 202 cells $\mathrm{mL}^{-1}$ で最 大となった。その後, 急速に減少し 5 月上旬には確認 されなくなった。2014 年はさらに 12 月下旬にも出現が 確認された。2015 年は過去 2 年より早く 1 月中旬に確 認され，3 月中旬まで低密度で推移した。 3 月下旬に 10 cells $\mathrm{mL}^{-1}$ を超えたが，4 月上旬から中旬にかけていっ

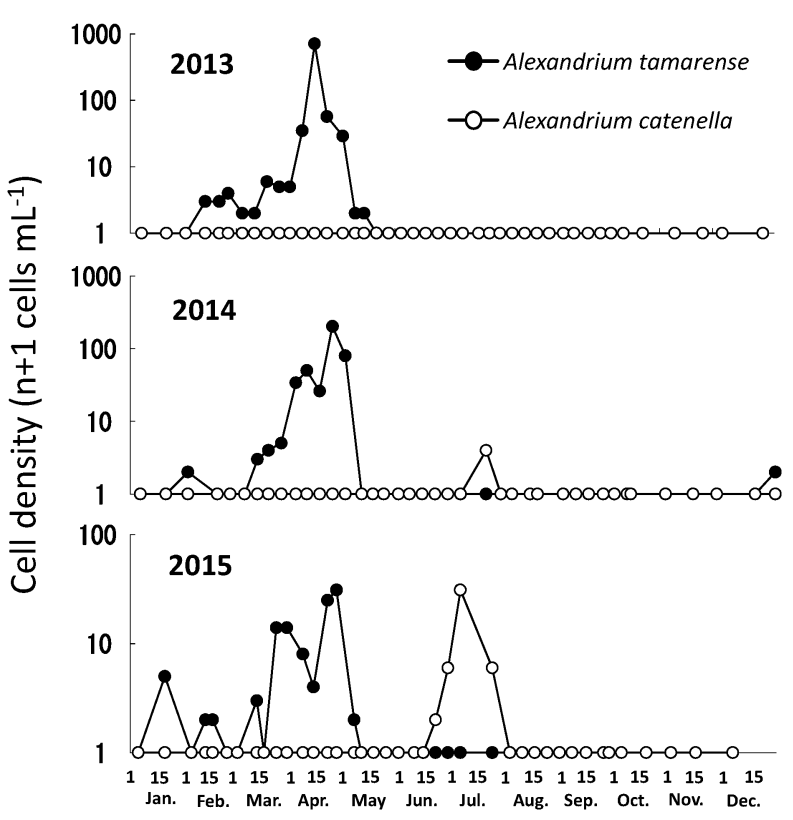

Fig. 2 Changes in cell densities of Alexandrium tamarense and A. catenella in Osaka Bay from 2013 to 2015. In order to display the logarithmic graph, 1 is added to the density to obtain the value on the vertical axis.

たん減少した。その後, 4 月下旬に再び増加して 4 月下 旬に 30 cells $\mathrm{mL}^{-1}$ で最大となった後急速に減少し， 5 月中旬には確認されなくなった。

Alexandrium catenella は, 2013 年は確認されず, 2014 年は 7 月中旬に 3 cells $\mathrm{mL}^{-1}$ で確認されたのみで あった。 2015 年は 6 月下旬に確認され， 7 月上旬に 30 cells $\mathrm{mL}^{-1}$ で最大となった後, 8 月上旬には確認されな くなった。

アカガイの毒量および毒成分の経時変化 Figure 3 に 2013 年から 2015 年のアカガイに打けるマウス毒力 並びに HPLC 毒力の推移を示した。

2013 年のマウス試験では 3 月上旬のサンプルから検 出限界 $\left(2 \mathrm{MU} \mathrm{g}^{-1}\right)$ を超え, 4 月上旬までは検出限界 近くで推移したが，4 月下旬にかけて上昇し 4 月 29 日 に期間最大の $15.2 \mathrm{MU} \mathrm{g}^{-1}$ となった。HPLC 毒力はマ ウス毒力より常に高傾向を示し, 同日に $35.4 \mathrm{MU}$ $\mathrm{g}^{-1}$ で最大となった。2014 年はマウス毒力で 1 月から 検出限界を超えており, HPLCでも同程度の濃度を示 していた。その後, 毒力はともに 3 月上旬まで $2 \mathrm{MU}$ $\mathrm{g}^{-1}$ 前後の濃度で推移した後徐々に上昇し，4 月 21 日 に期間最大の毒力を示し, マウス毒力と HPLC 毒力で それぞれ $50.6 \mathrm{MU} \mathrm{g}^{-1}, 40.3 \mathrm{MU} \mathrm{g}^{-1}$ となった。その 後 5 月上旬にかけて毒力は急速に減少したが, 中旬以 降 6 月上旬まで $10 \mathrm{MU} \mathrm{g}^{-1}$ 前後の濃度を維持し， 7 月 上旬まで規制值 $\left(4 \mathrm{MU} \mathrm{g}^{-1}\right)$ を上回る濃度であった。 さらに 7 月中旬以降 9 月までは規制值以下の濃度で 
あったが， 8 月および 10 月のサンプルにおいてマウス 毒力, HPLC 毒力とも濃度が再び上昇した。このよう に，マウス毒力と HPLC 毒力は期間を通じて概ね同様

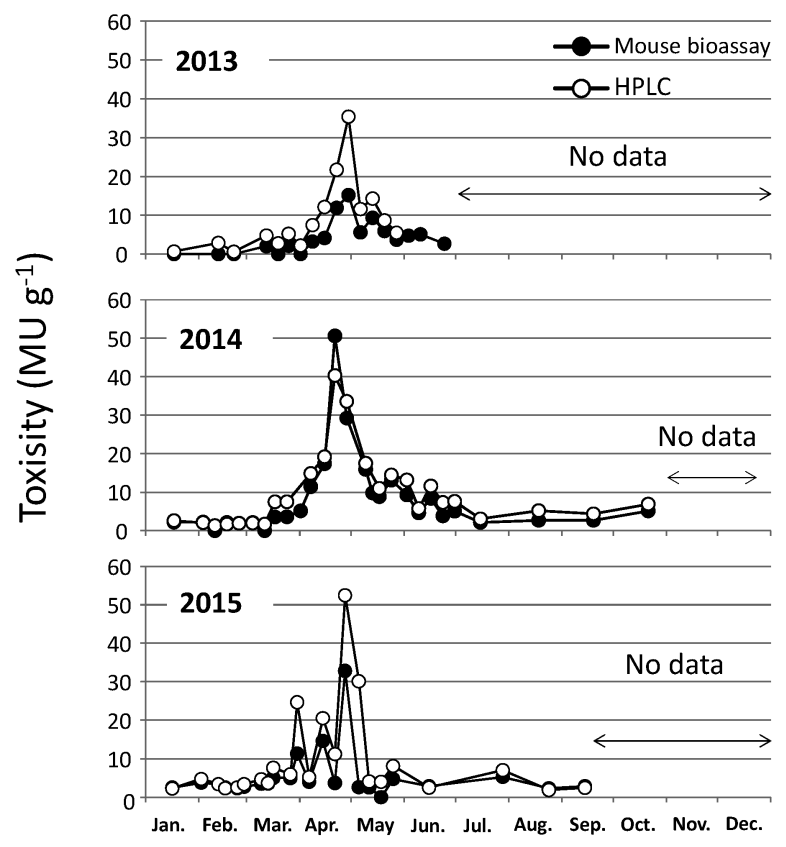

Fig. 3 Changes of toxicity in arc shell analyzed by mouse bioassay and high performance liquid chromatograph (HPLC) from 2013 to 2015.
の值であった。2015 年は 2014 年と同様，1月にはマウ ス毒力で陽性となった。マウス毒力は HPLC 毒力と同 様の毒力を示し， 3 月上旬まで 2-3 $\mathrm{MU} \mathrm{g}^{-1}$ の濃度で推 移した。その後 3 月中旬から毒力は上昇傾向となった が， 1 週ごとに増減し 4 月 27 日に最大となった。この ときマウス毒力と HPLC 毒力はそれぞれ $32.8 \mathrm{MU} \mathrm{g}^{-1}$, $52.4 \mathrm{MU} \mathrm{g}^{-1}$ を示した。5 月上旬以降は急速に減少した が 9 月のサンプルまで抢抢むねマウス試験の検出限界 である $2 \mathrm{MU} \mathrm{g}^{-1}$ を上回る值であった。

以上のように, アカガイの毒力は 3 年ともマウス毒 力, HPLC 毒力ともに同様の変動傾向を示したが, 2013 年の 1 月-3 月を除き, 調査を行ったほぼすべての サンプルでマウス試験の検出限界を下回ることはなかっ た。

Figure 4 に 2013 年から 2015 年のアカガイにおける 各年の毒成分組成の変化を示した。 3 年間の調查期間を 通じて最も高い割合（平均約 $55 \%$ ）を占めたのは GTX2 およびGTX3 であった。また，弱毒成分である C1, C2 も一定割合で（15-20\%）検出された。GTX1 抢よびGTX4は 2013 年には 4 月 15 日から 5 月 13 日 のサンプルで, 2014 年は 3 月 17 日から 6 月 2 日のサ ンプルおよび 6 月 16 日のサンプルで, 2015 年は 3 月 16 日， 5 月 25 日抢よび 3 月 30 日から 5 月 5 日のサン プルでそれぞれ検出された。GTX1 および GTX4 が増 加する期間は C1, C2 の割合も増加する傾向がみられ，
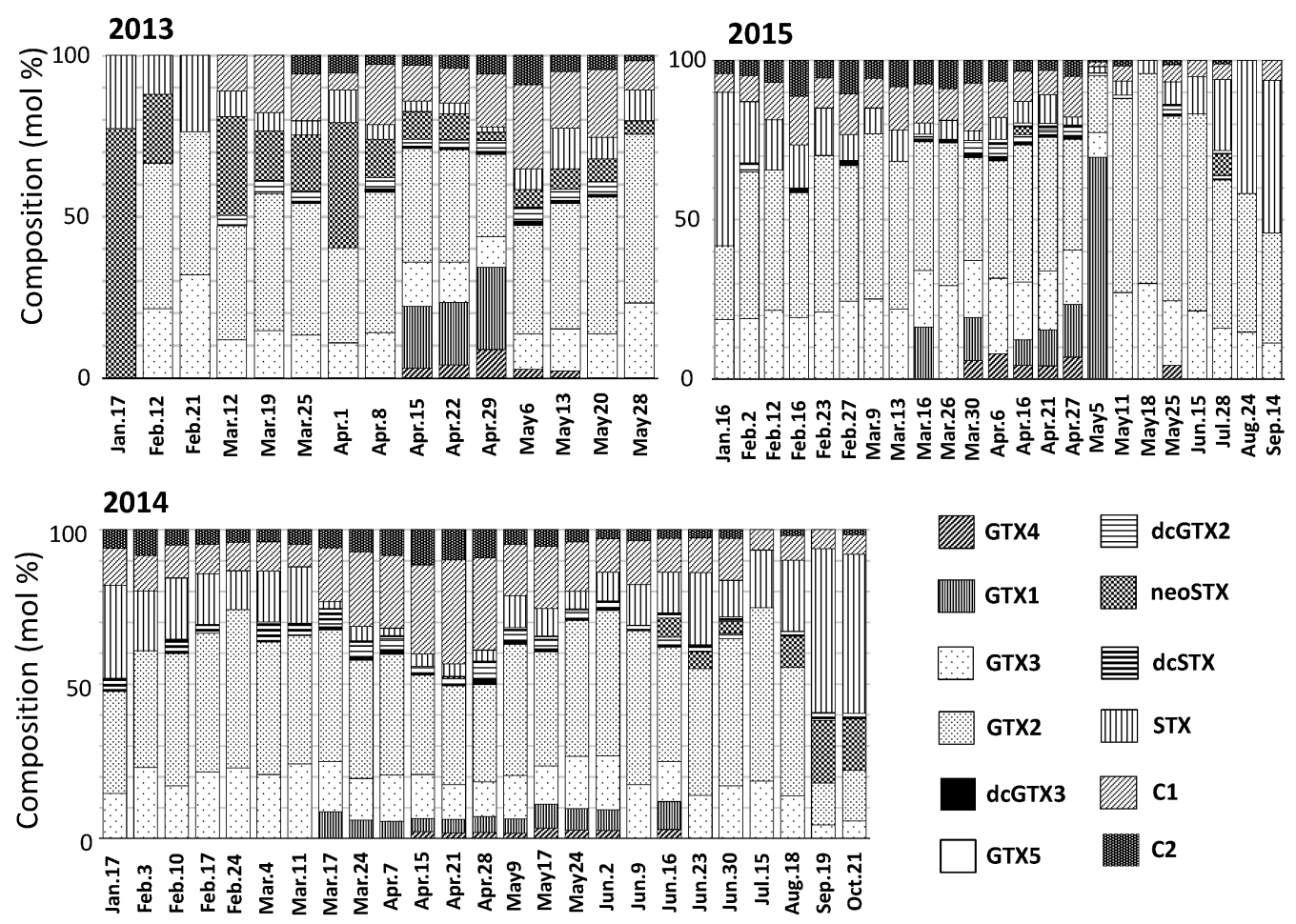

Fig. 4 Changes in composition of toxin components in arc shell from 2013 to 2015. 
GTX1 および GTX4 の増減傾向は C1, C2 の増減傾向と 類似していた。STXは GTX1 および GTX4 と異なる推 移を示し，GTX1，4の割合が低くなるとSTX は高い割 合を占める傾向があった。すなわち, 毒化ピークから離 れるに従い全体に占める割合は高くなった。neoSTX は 2013 年には比較的高い割合で検出され，他の年は 2014 年の後半を除くとほとんど検出されなかった。 dcGTX3, dcGTX2, dcSTX は検出されたがいずれも低 い值であった。また，GTX5 および GTX6 は調査期間 中まったく検出されなかった。

トリガイの毒量および毒成分の経時変化 Figure 5 に 2013 年から 2015 年のトリガイにおけるマウス試験 による毒力推移と, HPLCの分析結果から Oshima ${ }^{13)}$ が 示した比毒性に従いマウス毒性值に換算したもの （HPLC 毒力）を併せて示した。2013 年はマウス試験, HPLC 毒力とも 3 月下旬までマウス試験の検出限界 $(2$ $\left.\mathrm{MU} \mathrm{g}{ }^{-1}\right)$ 以下で推移していたが，4 月上旬のサンプル でマウス毒力, HPLC 毒力とも規制值 $\left(4 \mathrm{MU} \mathrm{g}^{-1}\right)$ を 上回った。その後, 4 月下旬まで毒力は大きく増加し, 4 月 22 日のサンプルで最大となった。そのときのマウ ス毒力, HPLC 毒力はそれぞれ $44.8 \mathrm{MU} \mathrm{g}^{-1}, 52.9 \mathrm{MU}$ $\mathrm{g}^{-1}$ であった。その後毒力は速やかに減少し，6月上旬 に規制值を下回り，下旬には検出されなくなった。 2014 年は 3 月上旬までマウス試験は実施しなかったが,

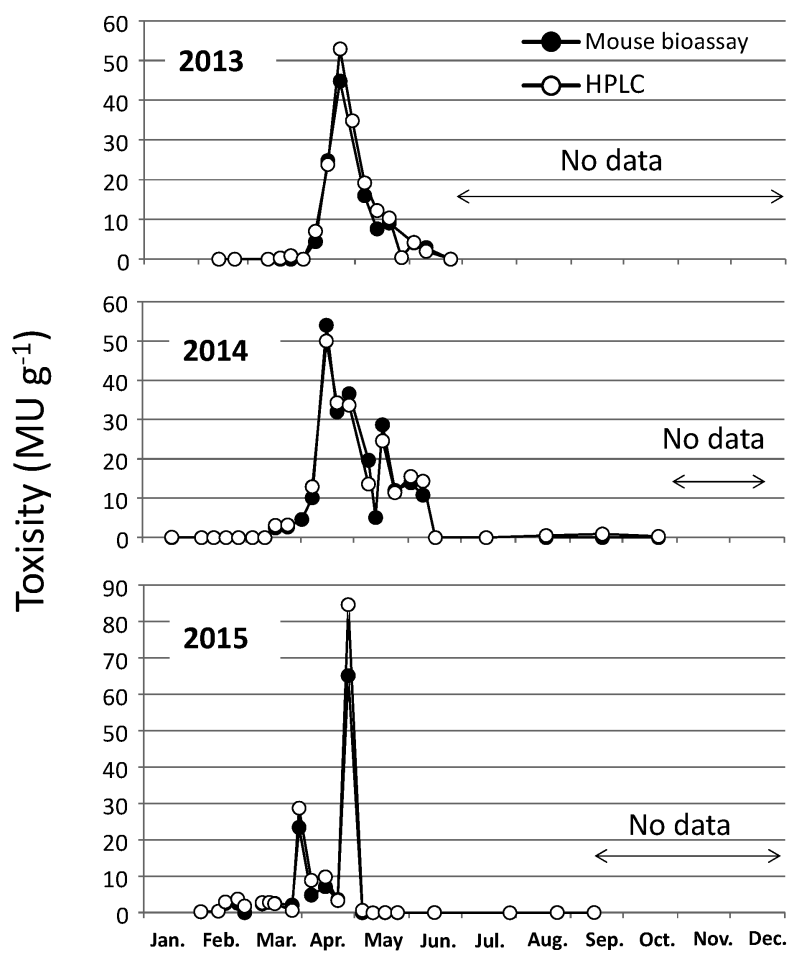

Fig. 5 Changes of toxicity in Japanese cockle analyzed by mouse bioassay and high performance liquid chromatograph (HPLC) from 2013 to 2015.
HPLC 分析では麻痺性貝毒成分は全く検出されなかっ た。しかし， 3 月中旬のサンプルでマウス毒力, HPLC 毒力とも $2 \mathrm{MU} \mathrm{g}^{-1}$ を上回った後に大きく増加し，4月 15 日に最大の毒力を示し, マウス毒力で $54.0 \mathrm{MU} \mathrm{g}^{-1}$, HPLC 分析からの換算値で $50.0 \mathrm{MU} \mathrm{g}^{-1}$ となった。そ の後, 毒力は 5 月中旬まで速やかに減少したが， 5 月 17 日のサンプルで再び増加した。なお， 5 月下旬以降 は急速に減少し 6 月中旬以降は検出されなくなった。 2015 年はマウス毒力, HPLC 毒力とも 2 月中旬のサン プルで $2 \mathrm{MU} \mathrm{g}^{-1}$ を上回った。3 月下旬まで $2 \mathrm{MU} \mathrm{g}^{-1}$ 前後で推移した後, 3 月 30 日に濃度上昇がみられた が, すぐに減少し，4月 21 日にはマウス毒力, HPLC 毒力とも規制值を下回った。その後, 4 月 27 日のサン プルで再び急増し, 期間最大の毒力（マウス毒力, HPLC 毒力でそれぞれ $\left.65.2 \mathrm{MU} \mathrm{g}^{-1}, 84.7 \mathrm{MU} \mathrm{g}^{-1}\right)$ を 示したが 1 週間後の 5 月 5 日のサンプル以降, マウス 毒力, HPLC 毒力とも検出限界以下の低濃度となった。

以上のように, トリガイの毒力は 3 年ともマウス毒 力, HPLC 毒力とも同様の変動傾向を示し, アカガイ より両分析の值は近似していた。また, アカガイとは異 なり, 春季の原因プランクトンが出現する時期以外は, 麻痺性貝毒成分は検出されないことが多かった。

Figure 6 に 2013 年から 2015 年のトリガイに抢ける 各年の毒成分組成の変化を示した。3 年間の調査期間を 通じて最も高い割合（約 30-60\%）を占めたのは弱毒成 分の $\mathrm{C} 1$ 抢よびC2であった。GTX1 打よびGTX4 は 2013 年には 4 月 8 日から 5 月 20 日のサンプルで, 2014 年は 3 月 17 日から 6 月 9 日までのサンプルで, 2015 年は 2 月 16 日から 3 月 16 日抢よび 3 月 30 日か ら 4 月 27 日のサンプルで高い割合 (GTX1+4 で約 2040\%）で検出された。GTX2 おょび GTX3 の検出期間 はGTX1 およびGTX4 とほぼ同様であったが, GTX1, 4 よりも長期間にわたり検出される傾向があった。STX は毒化した期間の後半に検出されることが多く, 2014 年の 10 月についてはほぼ $100 \%$ となった。neoSTX は 2013 年には比較的高い割合で検出されたが他の年につ いては低い割合にとどまった。dcGTX2 および dcGTX3 は低い割合ではあるが, GTX1, 4 と同様の時 期に検出された。dcSTX は検出されたがいずれも低い 割合であった。また, アカガイ同様, GTX5 拈よび GTX6 は調査期間中まったく検出されなかった。

\section{考察}

大阪湾における麻痺性貝毒原因プランクトンの増殖と 麻痺性貝毒発生レベル 2013 年から 2015 年に抢い て, 麻痺性貝毒原因プランクトンは A. tamarense が 3 年間共通で 3 月から 4 月後半にかけて出現した。一方,

A. catenella は 7 月を中心に増殖した。また, この 2 種 

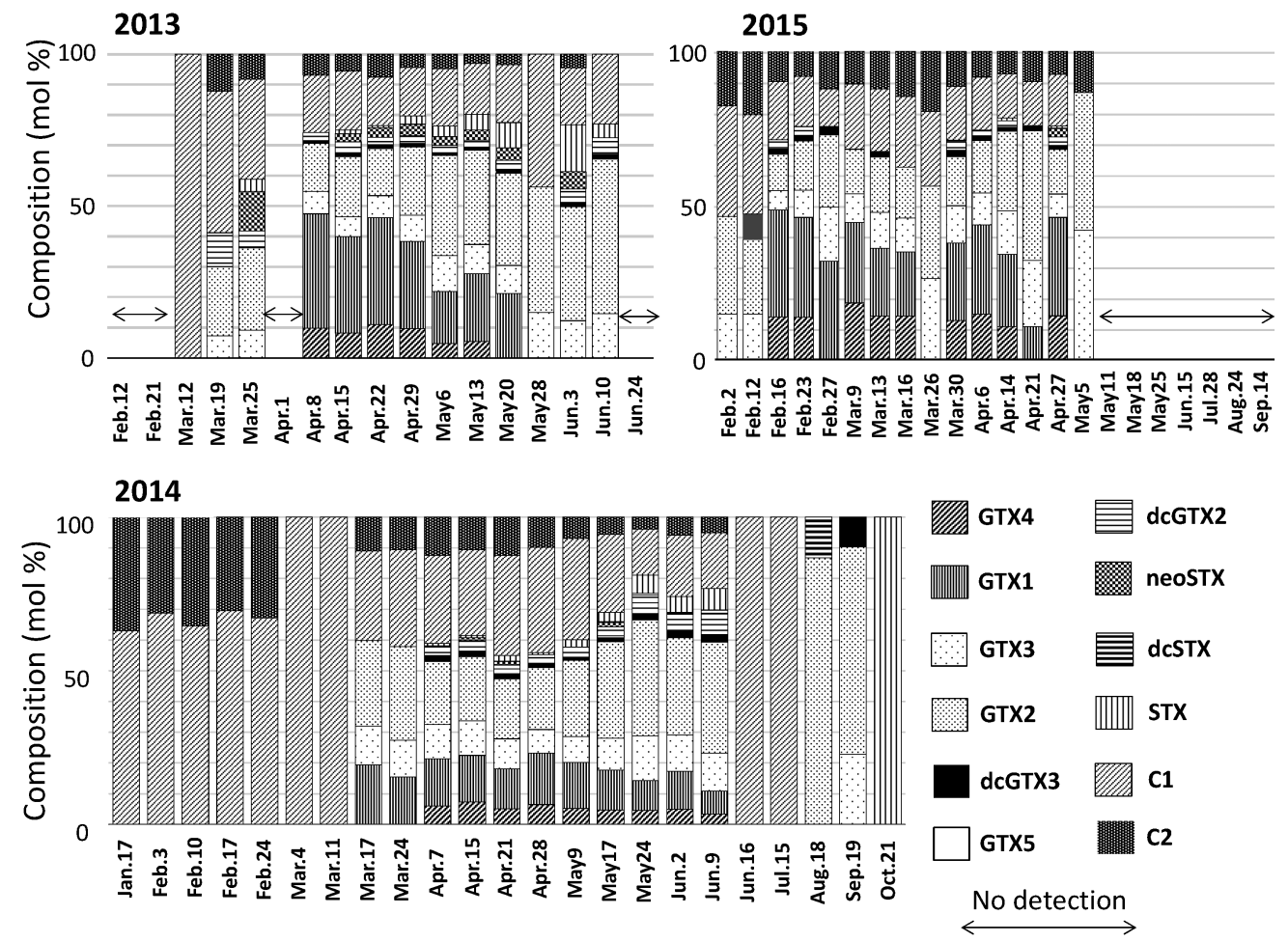

Fig. 6 Changes in composition of toxin components in Japanese cockle from 2013 to 2015.

以外の麻痺性貝毒原因種はモニタリング調査では確認さ れなかった。このことから, 本研究期間に抢ける麻痺性 貝毒原因種としては A. tamarense およびA. catenella で あることが推察された。ここで, John et al.は $A$. catenella-tamarenseグループの分子系統解析を行い, 5 つの分類群に分かれることを示した ${ }^{14)}$ 上でA. catenella の種名を廃棄することを提案した ${ }^{15)}$ 。この報告に従う とA. tamarense は A. fundyenseに, A. catenella は A. pacificum となるが，本件の是非については議論の途上 であることから本報告に抢いては従来通り A. tamarense 打よびA. catenella とした。A. tamarenseはいずれの年 も大阪府に抢ける警戒密度である 10 cells $\mathrm{mL}^{-1}$ を超え て確認された。山本ら ${ }^{10)}$ は 2002 年から 2016 年まで 15 年間の A. tamarense 出現状況をまとめ, 本研究期間 3 年間すべてを貝毒発生年, うち 2013 年, 2014 年を最 高細胞密度が 100 cells $\mathrm{mL}^{-1}$ を超える大規模発生年に 分類している。一方, マウス試験の最高毒力はアカガイ で 2013 年, 2015 年, 2014 年の順に高く, トリガイで は 2013 年, 2014 年, 2015 年の順に高くなっていた。 過去に麻痺性貝毒に暴露された二枚貝は有毒プランクト ンに対する摂䭒抵抗性を増し，今まで污染されたことの ないものよりも高いレベルまで毒を蓄積しうることが報 告されていることから, ${ }^{16)}$ A. tamarense の増殖レベルが 他の 2 年より低かった 2015 年にも高い毒力を示した可 能性が考えられる。一方, A. catenella は最大で 30 cells
$\mathrm{mL}^{-1}$ であり，大阪府の警戒密度である 500 cells $\mathrm{mL}^{-1}$ を大きく下回り低密度の発生にとどまった。したがっ て, 本研究期間に打㱠カガイ, トリガイの毒化に対 する影響は大きくなかったことが推察される。ただし，

A. catenella の最高細胞密度は増加傾向であったことか ら, 今後本種の増殖期間である夏季にも貝毒の発生リス クが高くなる可能性がある。

調查期間中, G. catenatum およびA. tamiyavanichii の出現は確認されなかった。この 2 種の毒成分とし て, 栄養細胞では GTX5 が多く検出されることが報告 されている。17,18) 本調査期間中, GTX5 は全く検出され ていないことから, 毒組成の観点からも2013 年から 2015 年の毒化原因種としては A. tamarense ないしは $A$. catenella であったことが推察される。

麻痺性貝毒原因プランクトンの出現とアカガイの毒 量, および毒成分組成の関係 アカガイを 3 年にわた り調査したが, 最も高い割合で存在した麻痺性貝毒成分 はGTX2 およびGTX3 であった。坂本, 小谷 ${ }^{19)}$ は呉湾 に抢けるA. tamarense 栄養細胞の毒量打よび毒成分を 調查し, C1 + C2 抢よび GTX1+GTX4 の 4 成分で 80 $\%$ 以上を占妃とを示した。さらに, 山本ら ${ }^{8)}$ も大阪 湾で発生した A. tamarense 赤潮について同様の結果を 示している。GTX1, GTX4 は主に 3 月中旬から 5 月上 旬に検出されたが, この期間は A. tamarense の増殖期 間に一致する。このことから，この期間のGTX1, 
GTX4 の増加は原因プランクトンの取り込久を反映し たものと思われる。二枚貝体内では $\mathrm{C} 1, \mathrm{C} 2$ は中性以上 でdcGTX2, 3 に変化する。20) しかし, 今回の結果では いずれの年も dcGTX2, 3 の割合は低く推移しており,

A. tamarense の増殖期間以外ではほとんど検出されない ことから, C1, C2 からの変換能は弱く, さらに変換さ れた dcGTX2, 3 は速やかに排出された可能性が考えら れた。一方， $\mathrm{N} 1-\mathrm{OH}$ 基は還元反応により $\mathrm{N} 1-\mathrm{H}$ 基へ変 換することで毒成分が変化し，GTX1，GTX4 は GTX2， GTX3 に変化する。 ${ }^{21)}$ さらに Sato et al. ${ }^{22)}$ はへムタンパ クの存在によりこの還元反応が触媒されることを報告し ている。アカガイは通常の軟体動物と異なり, 血液中に ヘム色素を持つエリスロクルオリンを含むことは広く知 られている。すなわち, GTX1, GTX4 がへムタンパク により触媒され，速やかに還元されることでGTX2， GTX3 が主成分になったと推測される。さらに前述の 還元反応により, 最終的に最も安定的な STXに変化す る23)が, 本調査においても毒化期間の後半になるほど STX の割合は増加した。この傾向は他の二枚貝類でも 確認されており，長期に毒を蓄積するAlaska butter clam Saxidomus giganteus では水管に毒が蓄積し STX が毒の主成分となっている。24) 本研究に抢いて, 2014 年 10 月にはアカガイでマウス毒力の増加が確認された が，比毒性の高いSTXの割合が増加することにより， 毒力の増加が確認されたと考えられる。

Alexandrium tamarenseの出現が確認されなかった 6 月以降の毒力データが存在する 2014 年の 8 月および 10 月, 2015 年の 7 月においてわずかながら毒力の上昇 がみられた。比較的高密度に A. catenella が確認された 2015 年の同種の出現時期は上述の通り 7 月であった。 この時のアカガイの毒組成をみると neoSTXが他のサ ンプルに比べ多く検出されている。加賀ほか25) は岩手 県沿岸に出現するAlexandrium 属数種の毒成分を分析 した結果, A. catenellaでは neoSTXが $\mathrm{C} 1+\mathrm{C} 2$ に次い で高い割合であることを示した。これらのことから， 2015 年の毒量の上昇は A. catenellaによるものであった 可能性が高い。一方, 2014 年については同様に 6 月以 降 neoSTX の割合が増加しているが, A. catenella は出 現しているが極めて低密度であったこと，A. catenella の出現時期と毒力の上昇時期が一致しないことから, 別 の要因が考えられる。このうち, 10 月の増加は前述の と抢り, 毒成分が STX へ変換することによる毒性值の 上昇の可能性があるが，6月の毒力増加時には栄養細胞 出現時期と同様に GTX1 抢よび GTX4 が検出されてい た。山本ら ${ }^{26)}$ は大阪湾に抢いて A. tamarenseないし $A$. catenellaのシストを調査したところ，多くの海域で $10^{3}$ cysts $\mathrm{cm}^{-3}$ を超える密度で存在することを明らかにし た。シストは栄養細胞に比べ, 約 6 倍の高い毒量を持
つとされている。 ${ }^{27)}$ Persson et al. ${ }^{28)}$ は, A. fundyense シ ストをカキに捕食させる室内実験を行った結果から，シ ストによる二枚貝の毒化の可能性を示唆している。すな わち, 原因プランクトンの増殖が確認されない時期にお ける毒量の上昇についてはシストの捕食による毒化の可 能性を考慮する必要があろう。

麻痺性貝毒原因プランクトンの出現とトリガイにおけ る毒量, および毒成分組成の推移 2015 年のトリガイ に抢いて最も高い割合を示した麻痺性貝毒成分は C 1 打 よび C2 であった。トリガイにおいてもアカガイ同様,

A. tamarense 増殖期間に GTX1 および GTX4 の濃度の 上昇が確認された。A. tamarense 出現の後半には STX の割合が増加していたが，アカガイほど顕著ではなかっ た。また，GTX2 および GTX3 は GTX1 おょび GTX4 の検出前後から検出され始めた。これまで大阪湾以外で のトリガイの毒化事例は少ないが, 長谷川ら 29) は愛知 県海域で 2014 年にトリガイが毒化したことを報告して いる。このときの原因プランクトンは本研究と同様,

A. tamarenseであったが, 本研究と同様毒の主成分は C 群であり，C1+C2 で $80 \%$ を占めていた。すなわち, トリガイでは C1, C2, GTX1, GTX4 のいずれの成分も 変換される割合は低く, 残存したものが高い割合で検出 されたと考えられた。一方, 京都府海域で毒化したトリ ガイに拈ける毒成分は $\mathrm{C} 1+\mathrm{C} 2$ が約 $40 \%$ であったが， 次いでGTX5 抢よびGTX6が高い割合を占めてい た。 ${ }^{30)}$ 京都府の事例は原因プランクトンが A. tamarense ではなくG. catenatum であった。G. catenatum 栄養細 胞はGTX5，抢よびGTX6 を主成分として持つことか ら，これを直接反映したものと考えられる。これらの事 例を併せて考えるとトリガイは体内での毒成分の変換が 弱く, 打打むね現場プランクトンの毒成分を反映した毒 成分になると考えられた。

Alexandrium tamarense の出現が確認されなかった 6 月以降の毒力データが存在する 2014 年, および 2015 年のトリガイに打けるマウス毒力は, ほぼ検出限界以下 の値で推移した。2015 年はこの時期 HPLC 分析におい ても毒成分は検出されなかったが，2014 年の試料では 毒成分が検出されていた。この時の検出された毒成分は C1 抢よびGTX2, GTX3, dcSTX, dcGTX3 であり, 10 月のみ STXが検出された。たたし，これらはいずれも ごく微量であり, プランクトンが消失した後は, 短期間 でマウス毒力あるいは HPLC で検出される毒成分が減 少していた。以上のことから，トリガイに拈いて毒成分 は比較的速やかに排出されると推測され, 強毒成分への 変換が弱いことと併せ, アカガイより毒力の低下が早い ことが推察された。

アカガイ, トリガイにおける毒化, 减毒の差異 アカ ガイとトリガイに抢ける毒化過程に扔いて, 本研究期間 
における主たる麻痺性貝毒原因種と考えられる $A$. tamarense の出現のピークとアカガイ, トリガイの毒化 のピークを比較した。A. tamarenseの出現時期は, 2013 年は 4 月中旬に 1 回ピークが, 2014 年は 4 月上旬 と下旬, 2015 年は 3 月下旬と 4 月下旬に 2 回のピーク があった。これに対し, マウス毒力のピークはアカガイ では 2013 年は 4 月下旬, 2014 年は 4 月中旬に 1 回, 2015 年は 3 月下旬, 4 月中旬, 4 月下旬の 3 回, トリ ガイでは 2013 年が 4 月中旬に 1 回, 2014 年 4 月中旬, 5 月中旬, 2015 年が 3 月下旬, 4 月下旬の 2 回とトリ ガイでは概ね A. tamarense のピークと毒化のピークが 同時期であったが，アカガイでは 1 週間から 10 日のタ イムラグがあった。このようにアカガイについては高毒 化するまでに比較的日数を要すると考えられることか ら, 毒化初期の対応として, 原因プランクトンの増加を 指標にリスクを管理することは可能であろう。ただし， 後述のと抢り年を通して毒化が継続している可能性もあ ることから漁期前の毒化レベルを確認するといった処置 も必要と思われる。トリガイについてはこれまでは現行 の警戒密度 $\left(10\right.$ cells $\left.\mathrm{mL}^{-1}\right)$ で問題が起きていないが， 原因プランクトンの増殖ピークと毒化のピークがほぼ同 時期であるといった特性を考慮すると, プランクトンの 増加と同時に毒化が進行する可能性があることから，ア カガイより一段低い密度を警戒值に設定し早期に対応す る必要があると考えられる。

一方, 減毒過程に扔いて最も顕著な違いは原因プラン クトンが消滅した後の毒成分の保持期間であった。すな わち, アカガイでは原因プランクトンが確認されなく なった後も低いレベルではあるが麻痺性貝毒が検出され るのに対し，トリガイではほぼ検出されなくなっていた。

Fig. 7 に 2002 年から 2016 年に大阪府が実施したアカ ガイ, トリガイ怙よびアサリのマウス試験のデータ (http://www.pref.osaka.lg.jp/shokuhin/shokutyuudoku / kai.html, 2016 年 12 月 8 日）を用いて，それぞれの貝 種の年間最高毒量と規制日数の関係を解析した結果を示 した。回帰直線の傾きはアサリで最も小さく, トリガ イ, アカガイの順に大きくなったが，このことはすなわ ち, 同じ二枚貝であっても, アサリ, アカガイ, トリガ イでは高毒化しても減毒する速度が貝種によって異なる ため規制日数の期間に差が出てくることを示しており, アサリでは高毒化しても速やかに減毒するため規制日数 が短く, 逆にアカガイでは低い毒量でも減毒が遅く, 規 制日数が長くなると考えられる。上述のと抢り, アカガ イではトリガイに比べ毒成分の変換能が高く, 強毒成分 であるGTX2, GTX3, 抢よびSTXが原因プランクト ン消滅後も長期間検出される。このことがアカガイにお いて長期間毒を保持し続ける要因の一つと考えられる。 さらに, アカガイ, トリガイで毒化後期に部位別に毒量

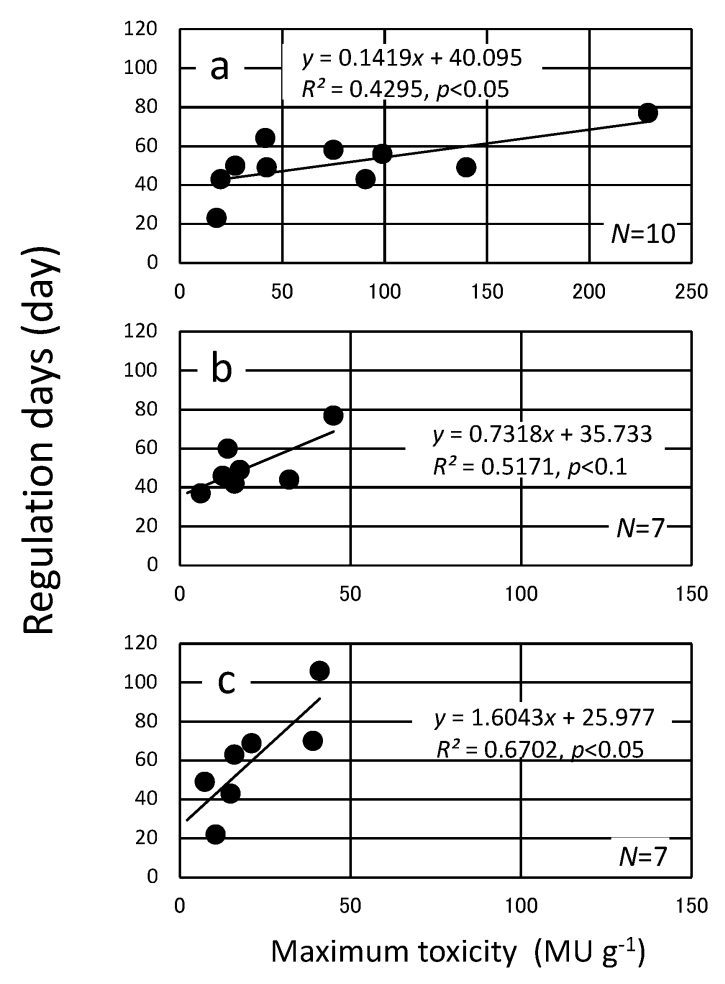

Fig. 7 Relationships between maximum toxicity and regulation days in bivalves from 2002 to 2016: (a) short necked clam, (b) Japanese cockle, (c) arc shell. Data was obtained from Osaka Prefectural Fisheries Division.

を検討した結果, アカガイでは筋肉部分に毒が多く存在 したのに対し, トリガイでは内臓にほとんどの毒が存在 していた (山本 未発表)。また愛知県に打けるトリガ イの毒化事例でも可食部である斧足の毒量は低いことが 示されている。29)一般的には有毒プランクトンが最初に 取り込まれる消化管や中腸腺に総毒量の過半が含まれる ことはよく知られている。 ${ }^{20)}$ が, アカガイでは摄取した 毒成分が筋肉部にも蓄積され, 筋肉部に蓄積した毒成分 は排出が遅いことが推測された。このことにより, アカ ガイについては原因プランクトンの消滅後も一定の警戒 レベルを維持する必要があると考えられる。アカガイと 比較するとトリガイでは減毒も早く, 毒がほぼ完全に消 滅する傾向が確認されたため, これまで同様原因プラン クトンの動向に注意しつつ, 原因種が減少した場合警戒 レベルを下げられる可能性も考えられる。ただし, 京都 府に抢けるトリガイでは原因プランクトン消減後も約 1 か月半程度毒化が継続している。30)トリガイについては いまだ事例が少ないこともあり, 今後も知見を蓄積する 必要がある。

\section{謝辞}

本研究を行うにあたり, サンプリングにご協力頂いた 
泉佐野漁業協同組合高倉智之前組合長，大伍健一氏，大 和谷孝義氏，大和谷忠和氏，岡田壮史氏をはじめとする 泉佐野漁協の底曳き網漁業者の皆様にはこの場を借りて 御礼申し上げます。分析用標準品のうち GTX1, GTX2, GTX3, GTX4, dcGTX2, dcGTX3, C1, C2, neoSTX は農 林水産省消費安全局から配布されました。また, dcSTX は東北大学名誉教授大島泰克博士より, GTX5, GTX6 は水産研究・教育機構中央水産研究所渡邊龍一 博士よりそれぞれ分与いただきました。さらに，STX は水産研究・教育機構中央水産研究所瀬戸内海区水産研 究所にて製造したものを広島大学浅川学教授に定量して いただきました。大阪府水産課の大道斉氏ならびに新瀬 幾恵氏には行政によるマウス試験結果をご教示いただき ました。大阪府立環境農林水産総合研究所水産技術セン ター職員の方々, 特に横松宏幸技師には貝毒抽出におい て多大なるご協力をいただきました。ここに記して深く 感謝の意を表します。本研究の一部は農林水産省レギュ ラトリーサイエンス新技術開発事業「課題名：貝毒リス ク管理措置の見直しに向けた研究」で実施しました。

\section{文献}

1）左子芳彦. 有毒渦鞭毛藻 Alexandrium の生活環と広域 化. 月刊海洋 1995; 27: 628-635.

2) Fukuyo Y, Imai I, Kodama M, Tamai K. Red tides and other harmful algal blooms in Japan. In: Max-Taylor FJR, Trainer VL (eds). Harmful Algal Blooms in the PICES Region of the North Pacific, PICES Scientific Report No. 23. Institute of Ocean Sciences, Sidney, Canada. 2002; pp. 720.

3) Imai I, Yamaguchi M, Hori Y. Eutrophication and occurrences of harmful algal blooms in the Seto Inland Sea, Japan. Plankton Benthos Res. 2006; 1: 71-84.

4）濱野米一, 川津健太郎, 塚本定三. 大阪湾における麻痺 性貝毒による二枚貝の毒化. 大阪府立公衆衛生研究所報 告 $2002 ; 40: 11-18$.

5）山本圭吾. 2002 年春期に大阪湾東部海域で発生した麻痺 性貝毒について. 大阪府立水産試験場研究報告 2004; 15: $1-8$

6）城 久. 大阪湾における富栄養化の構造と富栄養化が 漁業生産におよぼす影響について. 大阪府水産試験場研 究報告 $1986 ; 7$ : 1-174.

7）山本圭吾, 中嶋昌紀, 田㴊敬一, 濱野米一. 2007 年春期 に大阪湾で発生したAlexandrium tamarense 新奇赤潮と 二枚貝の高毒化. 日本プランクトン学会報 2009; 56: 13-24.

8) Yamamoto K, Matsuyama Y, Ohmi H, Ariyama H. Diel vertical migration of the toxic dinofragellate Alexandrium tamarense, temporal changes of associated environmental factors and cell toxin content during the course of a largescale bloom. Nippon Suisan Gakkaishi 2010; 76: 877-885 (in Japanese with English abstract).

9）山本圭吾，大美博昭，佐野雅基． 2007 年春期に淀川感潮 域で発生した有毒渦鞭毛藻 Alexandrium tamarense 赤潮 とシストの分布. 日本プランクトン学会報 $2011 ; \mathbf{5 8}$ : 136-145.

10）山本圭吾, 中嶋昌紀, 今井一郎. 長期モニタリングデー
タからみた大阪湾における環境変化と有毒渦鞭毛藻 Alexandrium tamarense ブルーム規模の拡大. 日本プランク トン学会報 2017; 64: 11-21.

11) Nagai S, Miyamoto S, Ino K, Tajimi S, Nishi H, Tomono J. Easy detection of multiple Alexandrium species using DNA chromatography chip. Harmful algae 2016; 51: 97106.

12）社団法人日本食品衛生協会. 食品衛生検査指針理化学編 2005; 3: 673-680.

13) Oshima Y. Post column derivatization liquid chromatographic method for paralytic shellfish toxins. J. AOAC Int. 1995; 78: 528-532.

14) Uwe J, Litaker RW, Montresor M, Murray S, Brosnahan ML, \& Anderson D. M. Formal revision of the Alexandrium tamarense species complex (Dinophyceae) taxonomy: the introduction of five species with emphasis on molecular-based (rDNA) classification. Protist 2014; 165: 779-804.

15) Uwe J, Litaker RW, Montresor M, Murray S, Brosnahan $\mathrm{ML}$, Anderson DM. Proposal to reject the name Gonyaulax catenella (Alexandrium catenella) (Dinophyceae). Taxon 2014; 63: 932-933.

16) Twarog BM. "Immunity" to paralytic shellfish toxin in bivalve molluscs. In Proceedings of the Second International Symposium on Coral Reefs 1974; Vol. 1: 505-512.

17) Oshima Y, Sugino K, Itakura H, Hirota M, Yasumoto T. Comparative studies on paralytic shellfish toxin profile of dinoflagellates and bivalves. In: Graneli E, Sundstorm B, Edler L, Anderson DM (eds). Toxic Marine Phytoplankton. Elsevier, Amsterdam. 1990; 391-396.

18）相良剛史, 谷山茂人, 吉松定昭, 高谷智裕, 橋本多美 子, 西堀尚良, 西尾幸郎, 荒川修. 瀬戸内海播磨灘で発 生した有毒渦鞭毛藻 Alexandrium tamiyavanichii と毒化 ムラサキイガイの毒性と毒成分. 食品衛生学雑誌 2010; 51: 170-177.

19）坂本節子, 小谷祐一。呉湾に発生したAlexandrium tamarenseの麻痺性貝毒量および毒成分組成の株間にお ける変異. 南西海区水産研究所研究報告 1998; 31: 4552.

20）村上りつ子, 野口玉雄. 麻ひ性貝毒 最近の知見を中心 に. 食品衛生学雑誌 $2000 ; 41: 1-10$.

21) Sato S, Sakai R, Kodama M. Identification of thioether intermediates in the reductive transformation of gonyautoxins into saxitoxins by thiols. Bioorg. Med. Chem. Lett. 2000; 10: 1787-1789.

22) Sato S, Takata Y, Kondo S, Kotoda A, Hongo N, Kodama M. Quantitative ELISA kit for paralytic shellfish toxins coupled with sample pretreatment. Journal of AOAC International 2014; 97: 339-344.

23) Shimizu Y, Yoshioka M. Transformation of paralytic shellfish toxins as demonstrated in scallop homogenates. Science 1981; 212: 547-549.

24) Kvitek RG, Beitler MK. Relative insensitivity of butter clam neurons to saxitoxin: A pre-adaptation for sequestering paralytic shellfish poisoning toxins as a chemical defense. Marine ecology progress series. Oldendorf 1991; 69: $47-54$.

25) Kaga S, Sekiguchi K, Yoshida M, Ogata H. Occurrence and toxin production of Alexandrium spp. (Dinophyceae) in coastal waters of Iwate Prefecture, Japan. Nippon Suisan Gakkaishi 2006; 72: 1068-1076 (in Japanese with English abstract).

26）山本圭吾, 鍋島靖信, 山口峰生, 板倉茂. 2006 年およ 
び 2007 年の大阪湾における有毒渦鞭毛藻 Alexandrium tamarense と A. catenella シストの分布と現存量. 水産海 洋研究 2009; 73: 57-66.

27) Oshima Y, Bolch CJ, Hallegraeff GM. Toxin composition of resting cysts of Alexandrium tamarense (Dinophyceae). Toxicon 1992; 30: 1539-1544.

28) Persson A, Smith BC, Wikfors GH, Quilliam M. Grazing on toxic Alexandrium fundyense resting cysts and vegetative cells by the eastern oyster (Crassostrea virginica).
Harmful Algae 2006; 5: 678-684.

29）長谷川晶子, 早川大輔, 中村瑞那, 秦 眞美, 山下照 夫, 皆川洋子. 2014 年シーズン愛知県においてマウス法 規制值を超えた麻痺性貝毒の分析. 愛知県衛生研究所報 2015; 65: 23-30.

30）尾崎 亿, 中西雅幸. ELISA 法を用いて測定したトリガ イ軟体部毒量と公定法毒力との関係. 京都府農林水産技 術センター海洋センター研究報告 2016; 38: 13-18. 